\title{
Sovereign Debt Restructurings in Belize: Debt Sustainability and Financial Stability Aspects
}

\author{
Tamon Asonuma \\ International Monetary Fund, U.S.A. \\ tasonuma@imf.org \\ Michael G. Papaioannou \\ International Monetary Fund, U.S.A. \\ mpapaioannou@imf.org \\ Gerardo Peraza \\ International Monetary Fund, U.S.A. \\ gperaza@imf.org \\ Kristine Vitola \\ International Monetary Fund, U.S.A. \\ kristine.vitola@hotmail.com \\ Takahiro Tsuda ${ }^{1}$ \\ Ministry of Finance, Japan \\ takahiro.tsuda@mof.go.jp
}

\begin{abstract}
This paper examines the causes, processes, and outcomes of the two Belize sovereign debt restructurings in 2006-07 and in 2012-13, which occurred outside an IMF-supported program. It finds that the motivation for the two debt restructurings differed, as the former was driven by external liquidity concerns while the latter was motivated by a substantial increase in the coupon rates and future fiscal solvency concerns. Despite differential treatment between residents and non-residents, both 2006-07 and 2012-13 debt exchanges were executed through collaborative engagement, due in part to the existence of a broad-based creditor committee and the authorities' effective communication strategy. However, while providing temporary liquidity relief, neither of the debt restructurings properly addressed long-term debt sustainability concerns. Going

1 Asonuma: Research Department, International Monetary Fund, $70019^{\text {th }}$ Street, N.W. Washington, D.C. 20431 USA, tasonuma@imf.org; Papaioannou (corresponding): Monetary and Capital Markets Department, International Monetary Fund, 700 19 ${ }^{\text {th }}$ Street, N.W. Washington, D.C. 20431 USA, mpapaioannou@imf.org; Peraza: Western Hemisphere Department, International Monetary Fund, 700 19 ${ }^{\text {th }}$ Street, N.W. Washington, D.C. 20431 USA, gperaza@imf.org; Vitola, Western Hemisphere Department, International Monetary Fund, 700 19 ${ }^{\text {th }}$ Street, N.W. Washington, D.C. 20431 USA, kristine.vitola@hotmail.com; Tsuda: Japanese Ministry of Finance, 3-1-1 Kasumigaseki Chiyoda-ku Tokyo 100-8940 Japan, takahiro.tsuda@mof.go.jp. The views expressed in this paper are those of the author(s) and do not necessarily represent the views of the IMF, its Executive Board, or IMF management.
\end{abstract}


forward, the success of the 2012-13 debt restructuring will still depend on the country's ability to strengthen fiscal efforts and the public debt management framework.

JEL Classification: F34, G15, H63

Keywords: Sovereign Defaults; Sovereign Debt Restructuring; External Debt; Inter-Creditor Equity; Serial Defaults.

\section{INTRODUCTION}

Typical determinants of restructurings, as well as defaults, are over-indebtedness (debt/GDP ratio) and illiquidity (rollover risks). Further, factors such as political instability and external shocks, in particular commodity price shocks and interest rate hikes, can exacerbate the adverse effects of these determinants. Market risk indicators, such as bond spreads, credit default swap prices and rating changes can generally be viewed as predictors of the risk of default and debt restructurings. Restructurings are rarely isolated events. They often follow or precede banking and currency crises and are associated with a decline in output, trade, and capital inflows.

Debt Sustainability Analyses (DSAs) are an important tool to assess the potential need and scope of a sovereign debt restructuring. In essence, DSAs analyze the conditions under which a government's primary balance (the budget balance excluding interest payments) is sufficiently high to stabilize or reduce the debt-to-GDP ratio (or, the debt-to-export ratio). The most basic DSA model can be reduced to two key variables: real interest rates (borrowing costs) and real growth. The larger the differential between interest rates and growth, the higher the primary budget balance that is needed just to stabilize the debt-to-GDP ratio.

The scope of haircuts (creditor losses) in bond restructurings has varied substantially, ranging from under 10 percent present value reduction (e.g., Uruguay, 2003, Dominican Republic, 2005) to over 80 percent (e.g., Dominica, 2004, Ecuador, 2009, Seychelles, 2010, Cote D' Ivoire, 2010, Greece, 2012). High participation rates, of more than 90 percent, have been the rule in recent sovereign bond exchanges. Evidence has shown that the size of the haircut in a restructuring is correlated with years of exclusion from capital markets and post-restructuring borrowing costs. In particular, higher haircuts (lower recovery values) are associated with longer periods of market exclusion and higher spreads after a crisis (Das et al., 2012).

The past international experience with sovereign crises and debt restructuring episodes provides us with several important insights for the case of Belize, which undertook two sovereign debt restructurings within a relatively short-time span and announced in Nov. 92016 that it intends to start restructuring discussions with holders on the 2038 sovereign bond. In 2006-07, facing an acute external liquidity shortage due to high debt service burden, Belize exchanged its various external debt instruments, including both loans and bonds, into one single U.S. dollar denominated bond ("super-bond") with face value of US\$547 million (34 percent of GDP in 2013). ${ }^{2}$ The exchange lengthened maturity and lowered coupon rates. ${ }^{3}$ Six years later, the Belizean authorities, this time driven mainly by a substantial increase in the coupon rates and future fiscal solvency concern, launched a second external debt restructuring, with a modest face value haircut as well as cash-flow relief through changes in both coupon and maturity structures.

Throughout the paper, external debt is defined as debt issued in foreign currencies and under the jurisdiction of a foreign court. It can be noted that the share of external public debt to the total public debt is around 84 percent of GDP.

3 Though maturity extension and lowering coupon rates over the short term without any face value reductions made it easier for both creditors and sovereigns to reach agreement on a deal, debt repayment burden became prominent over the medium and long term. 
This paper applies the case study method and analyzes several pertinent issues to Belize's sovereign debt restructurings, such as the evolution of the debtor-creditor relationship, including the role of the International Monetary Fund (hereafter IMF). We examine the case of Belize as it is unique in conducting its two debt restructurings outside of an IMF-supported program. Furthermore, it assesses the debt exchanges with regard to what has worked well and what has not, as the country's debt level still remains elevated even after the repeated debt exchanges. ${ }^{4,5}$ Specifically, the paper focuses on three key aspects:

- Cause - why did the country restructure its debt? This question will crystallize what macroeconomic indicators signaled the vulnerability of policies that ultimately led to debt restructurings.

- Process - how did the debtor-creditor relationship develop? It includes an analysis of the modalities and length of negotiation and communication with private, official bilateral and multilateral creditors. Are there any legal and operational characteristics that might have influenced the renegotiation process?

- Outcomes - did the restructuring fully address debt sustainability concerns? What was the impact on the liquidity and solvency conditions after each restructuring? What is the creditor loss along with the prospects for future market reaccess?

Even though Belize's two debt restructurings ultimately achieved preemptive, smooth, and broadly transparent processes, debt sustainability concerns remain. Differential treatment of residents and non-residents did not hamper the collaboration between the government and creditors. Also, although the investor base remained the same over time, the experience gained in the first debt restructuring helped to conclude the second debt restructuring in a relatively expedite way. ${ }^{6}$ However, while both restructurings were undertaken in a collaborative manner, the debt level remains high with potential risks of large contingent liabilities, implying that a substantial fiscal adjustment is still warranted to put the debt level on a sustainable path.

The rest of the paper is organized as follows. Sections 2 provides a brief review of the relevant literature. Section 3 and 4 investigate the causes, processes, and outcomes of the debt exchanges in 2006-07 and 2012-13, respectively. Analysis of the results of the first restructuring includes the question on what led the country to a subsequent debt exchange. Finally, conclusions are presented in Section 5.

\section{BRIEF LITERATURE REVIEW}

This paper relates to the empirical literature on case studies of sovereign debt restructurings (e.g., Reinhart and Rogoff, 2009; Sturzenegger and Zettelmeyer, 2006; Finger and Mecagni, 2007; Diaz-Cassou et al., 2008; Panizza et al., 2009; Das et al., 2012; Duggar 2013; Erce, 2013; Tomz and Wright, 2013; Asonuma and Trebesch 2016, Asonuma et al. 2017b). Among these

\footnotetext{
4 Reinhart, Rogoff, and Savastano (2003) argue that debt "intolerance" is highly linked to the phenomenon of serial default due to a vicious cycle in which default weakens a country's institutions in turn making subsequent default more likely. Asonuma (2016) theoretically explains that outcomes of previous renegotiation influence the borrowing costs of subsequent bond issuances, making repeated restructuring or default more likely.

5 IMF (2013a) provides a preliminary review of IMF policies and practices in light of recent experience in sovereign debt restructuring including Belize (2006-07 and 2012-13), the Dominican Republic (2004-05), Grenada (2004-05), Jamaica (2010, 2013) and St. Kitts and Nevis (2011-12). Jahan (2013) discusses some common features and asymmetries in three prominent debt restructurings in the Caribbean: Belize (2006-07), the Dominican Republic (2004-05) and Jamaica (2010). Diaz-Cassou et al. (2008) also provide detailed case studies on two restructuring episodes in the region: Belize (2006-07) and the Dominican Republic (2004-05) and Erce (2013) examines the role played by the IMF during sovereign debt restructurings in the region: the Dominican Republic (2004-05), Dominica (2004), Grenada (2004-05) and Jamaica (2010). Furthermore, Das et al. (2012) overview restructuring cases in the region: Belize (2006-07), Dominica (2004), the Dominican Republic (2004-05), Grenada (2004-05), and Jamaica (2010).

6 Several new legal terms included in the 2012-13 debt exchange offer attempted to improve transparency between the committee and the authorities in the event of a future debt distress.
} 
studies, Sturzenegger and Zettelmeyer, 2006, present detailed histories of default and debt crisis in seven emerging market (EM) during 1998-2005, while Diaz-Cassou et al., 2008, and Finger and Mecagni, 2007, review recent sovereign debt restructurings and IMF-supported programs in late-1990s and 2000s. Based on a large sample of debt restructurings over 1950-2010, Das et al., 2012, present new stylized facts on the outcome and process of debt restructurings, including on the size of net present value (NPV) haircuts, creditor participations and legal aspects. The current paper fills a gap in the literature of sovereign debt restructurings focusing specifically on "unique" case studies of the sovereign opting to restructure the debt outside the IMF-supported programs.

Another strand of literature discusses serial sovereign debt restructurings (e.g., Reinhart et al., 2003; Reinhart and Rogoff, 2005; Eichengreen et al., 2005; Catao et al., 2005; and Asonuma, 2016). Reinhart et al., 2003, and Reinhart and Rogoff, 2005, emphasize the role of past credit history in debt intolerance, while Eichengreen et al., 2003, stress that countries that have experienced "original sin," i.e., inability to issue bonds in their domestic currencies, must pay an additional risk premium when they borrow externally, thus increasing their solvency risks, as financial markets know that their inability is a source of financial fragility. Catao et al., 2009, point out that vicious cycles in sovereign credit histories arise due to output persistence - inertia of output dynamics which continues to stay at the previous level - combined with asymmetric information about output shocks. In contrast, Asonuma, 2016, shows theoretically and empirically that outcomes of previous debt restructurings influence the credit worthiness of sovereigns though increased borrowing costs. The paper contributes to the literature on serial sovereign debt restructurings by exploring in depth causes, processes, and outcomes of two serial debt restructurings in Belize in the case study analysis. ${ }^{7}$

\section{2006-07 DEBT RESTRUCTURING}

The 2006-07 debt restructuring achieved liquidity relief in a preemptive, collaborative, broadly transparent manner, but left solvency concerns unresolved. ${ }^{8}$ Prior to the debt exchange, Belize embarked on fiscal adjustment effort to address its vulnerabilities in fiscal and external positions. While this policy reduced new financing requirements in the following years, large financing gaps were still projected to remain in 2007 and beyond due to debt service of external commercial debt. In this light, the country undertook the debt restructuring and consolidated various instruments into one single benchmark bond. The deal was concluded in a collaborative manner with high creditor participation and introduced a single external bond with longer maturity than those of the original instruments, thus providing liquidity relief. The restructuring closed with strong creditor support based on the country's ability and willingness to put in place a strong fiscal consolidation effort.

\subsection{Background}

Highly expansionary macroeconomic policies in the late 1990s and early 2000s resulted in serious imbalances in the fiscal and external accounts (Annex 1). In the aftermath of the hurricanes and tropical storms in 2000-02, the government undertook aggressive efforts to stimulate economic growth through higher capital spending and lower taxes. This expansionary policy mix led to a soaring public debt level, high debt service costs, and widening of the external

Asonuma et al. (2017a) discuss two consecutive debt restructurings in Grenada. Moreover, Asonuma and Papaioannou (2016) explore domestic sovereign debt restructurings over decades.

8 Asonuma and Trebesch (2016) define Belize's 2006-07 restructuring as "weakly preemptive" as some payments were missed, but only temporarily and after the start of formal or informal negotiations with creditor representatives (no unilateral default). 
current account deficit. The overall deficit of the central government rose from an average of 3 percent of GDP in 1996-98 to about 9 percent of GDP in 2000-04. In addition, certain external financial transactions by a number of quasi-fiscal institutions contributed to the buildup of foreign liabilities. ${ }^{9}$ To secure financing, the government extensively borrowed from external commercial sources, including loans and bonds, which resulted in public debt surging from US\$ 599 million (72 percent of GDP) in 2000 to over US\$ 990 million (100 percent of GDP) by 2003, with 95 percent of the total public debt outstanding held by external creditors. Against this backdrop, IMF staff urged the authorities to implement immediately forceful measures to reduce the fiscal deficit. ${ }^{10}$

At the same time, Belize's external condition became more challenging owing in part to high world oil prices, declining export prices, and rising external debt service costs. Trade imbalances, coupled with surging debt service burden, led to significant current account deficits, which averaged 17.3 percent of GDP during the period 2001 through 2005. The large current account deficits were principally financed through a build-up of external public debt, which almost tripled from less than US\$400 million in 1998 to US\$1.1 billion in 2005. As debt service obligations rose and market financing became increasingly difficult to secure, the government resorted to financing from the central bank, whose international reserves fell below one month of import coverage by end-2005. This erosion of reserves left the Belizean economy highly vulnerable to both endogenous and exogenous shocks.

In addition, as a result of repeated refinancing operations the liquidity position deteriorated leading to a consistent rise in borrowing costs. The maturity structure of the external public debt at end-June 2006 exhibited a large share of short and medium-term debt, with 13 percent of liabilities falling due within a year and 25 percent of debt maturing in 1-5 years, forcing frequent refinancing. Since the refinancing was done by borrowing from external commercial markets at high interest rates, the cost of refinancing the external debt rose substantially, with the average effective interest rate at 11.25 percent. ${ }^{11}$

In face of the persistent high fiscal and current account deficits, in 2005 the government embarked on a forceful adjustment strategy. As a result of tax revenue measures and primary spending cuts, the overall deficit of the central government fell sharply from 8.6 percent of GDP in FY2004/05 12 to 3.3 percent in FY2005/06, while the primary balance shifted from a small deficit to a surplus of 3 percent of GDP. Partly in response to the tighter policy stance, the external current account deficit narrowed from 18 percent of GDP in 2005 to 14 percent in 2006. Subsequently, net international reserves position improved from 0.6 to 1.4 months of imports.

However, even with the adjustment effort, as well as prospective additional official financing, large financing gaps would remain in 2007 and beyond. ${ }^{13}$ Debt sustainability was also a major concern in the consultations between the government and IMF staff prior to the 2006-07 debt exchange, which indicated that without sustained primary surpluses the public debt would not

\footnotetext{
9 The Government of Belize assumed directly over 20 percent of GDP in external liabilities associated with a government guarantee on failed mortgage securitization scheme, and failed privatizations (IMF, 2006a).

10 IMF (2002a).

11 The rise in external commercial borrowing cost was partly a result of the downgrade of Belize's sovereign credit rating by Standard and Poor's and twice by Moody's in June 2005 (with refinancing interest rates, equivalent to nominal external interest rates increasing to 7.8 percent from 7.0 percent before the downgrade). S\&P's downgrades and negative outlook reflected mounting liquidity pressures that had been exacerbated by Belize's impaired market access (both official and commercial) and the government's worsening debt trajectory. The public sector's dire liquidity position in 2005 was weakened by massive amortization needs (as compared to available assets) and limited ability to access external financing which continued to suffer due to the unstable political situation. The government debt's deteriorating profile had been difficult to reverse due to persistent fiscal slippages and the government's assumption of Development Finance Corporation's debt as a result of the bank's financial distress (Standard and Poor's, 2013). Similarly, Moody's rating downgrades incorporated an assessment of Belize's increased external vulnerability and macroeconomic conditions that had not been consistent with fiscal and debt sustainability, as well as indications by the government of its intention to engage creditors in order to explore alternatives to improve Belize's external debt profile. Moody's believed that debt restructuring represented a credit event that was increasingly likely to materialize.

12 Belize fiscal year runs from April to March.

13 IMF (2006a).
} 
stabilize in the medium run. While the debt-to-GDP ratio would initially fall from $98 \frac{1}{2}$ percent at end-2005 to $84 \frac{1}{2}$ percent in 2012, it would shift back to an upward trend thereafter due to a rising interest bill. It was in this context that Belize sought to restructure its debt. ${ }^{14}$

\subsection{PROCESS}

The government announced the intention to restructure the country's sovereign debt in August 2006 (IMF 2006a). ${ }^{15}$ In the announcement, the authorities expressed willingness to recognize and work with a formal creditor committee representing holders of at least 51 percent of the affected debt (Buchheit, 2009). ${ }^{16}$ Bond prices, which had been declining since January 2006, slumped further after the authorities' announcement (Figure 1).

\section{Figure 1}

Belize Debt Restructuring, 2006-07: Price of New and Old Instruments (In percent of face value)

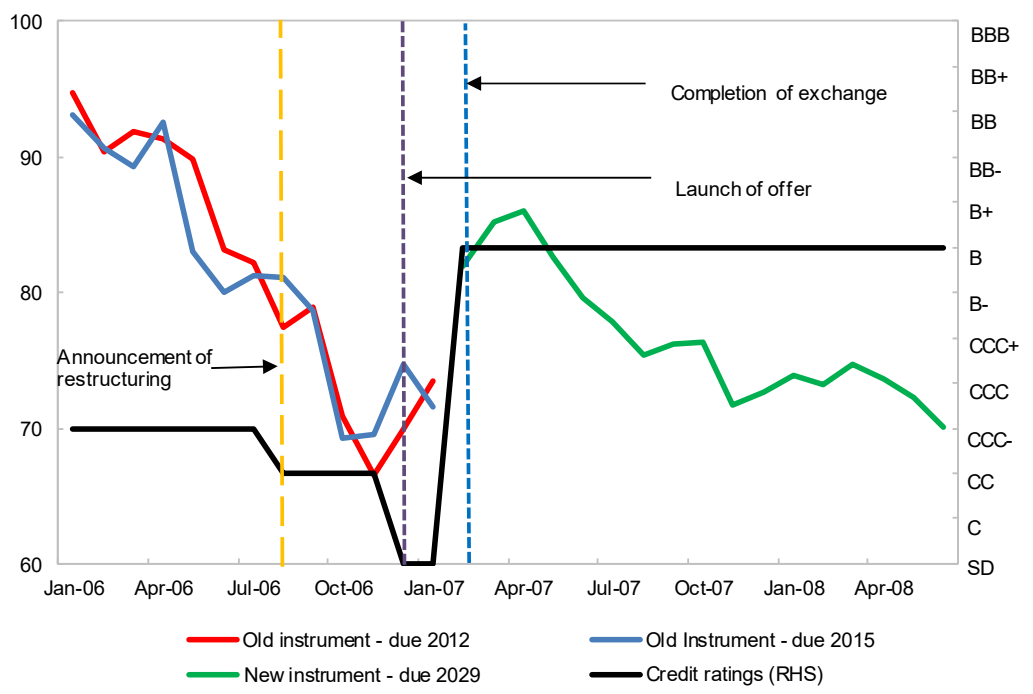

Sources: Bloomberg; Central Bank of Belize, Standard and Poor's.

The restructuring was undertaken preemptively, with subsequent arrears occurring due to missed coupon payments during the negotiation stage. The authorities had remained current on their debt obligations until its announcement of restructuring in August 2006, but in midSeptember they announced that debt service payments to two special purpose vehicles, which formed part of an issuance of insured loans, had not been made. ${ }^{17}$ The government explained that this action was driven by the country's acute liquidity difficulties and the need to conserve the very limited pool of usable reserves. At the same time, the authorities reiterated their intention to use their best efforts to continue servicing debt, pending an orderly restructuring of the debt.

The authorities targeted only external commercial debt, discriminating those creditors from domestic creditors and external official creditors. The authorities initially sought to restructure all of the government's bond indebtedness, external commercial loans, and insured loans. However,

\footnotetext{
14 IMF (2006b).

15 The Belize authorities appointed Houlihan Lokey, Howard \& Zukin as financial advisors in fall 2005 (Robinson, 2010). At the same time, BroadSpan Securities LLC was acting as a financial advisor to the Committee (Buchheit, 2009) and Cleary Gottlieb Steen \& Hamilton LLP was acting as a legal advisor to the government (Buchheit, 2009 and Belize Ministry of Finance, 2006).

16 Committee members included AIC Finance Limited, British-American Insurance Company, Caribbean Money Market Brokers Limited, First Citizens Asset Management Limited, First Global Financial Service Limited, Guardian Asset Management, Jamaica Money Market Broker Limited, National Commercial Bank (SVG), RBTT Merchant Bank Limited, RBTT Trust Limited, Republic Bank Limited, Sagicor Life Inc, Trinidad \& Tobago Unit Trust Corporation (Buchheit, 2009).

17 The structure of these two insured loan facilities was such that at inception, the government had to prepay six months of debt service into reserve accounts. The government's failure to make the scheduled coupon payments triggered the use of these reserve accounts to make the payments to bondholders.
} 
T-bills, domestic loans, and bilateral and multilateral claims were not eligible in the offer. ${ }^{18,19}$ This may be because (i) the authorities primarily aimed at addressing external vulnerabilities, as argued by Erce and Diaz-Cassou (2010); (ii) T-bills and domestic loans were difficult to restructure since the banks would need to be recapitalized; and (iii) the size of official credits was not large to help mitigate liquidity pressure. Such creditor discrimination did not seem to raise any apparent intercreditor equity concerns.

The existence of a broad-based creditor committee and the authorities' effective and broadly transparent communication strategy facilitated the smooth debt renegotiation (Buchheit and Karpinski, 2007, Buchheit, 2009). The creation of the creditor committee differs from those formed in the 1980s and 1990s in certain aspects: establishing certain criteria for formation of committee and its procedural rules and incorporating elements that enhanced dialogue and participation among creditors in past restructurings cases (Buchheit, 2009, Li et al., 2010). The creditor committee was engaged through an open dialogue with the authorities, which attempted to keep transparency in dissemination of all relevant macroeconomic data. ${ }^{20}$ The focus of discussion centered on projections of growth, fiscal consolidation, and debt dynamics which were important inputs to assess Belize's repayment capacity and financing gaps. Details of the government's indicative scenarios presented to creditors in October 2006 are shown in Table 1 below.

Table 1

Belize Debt Restructuring, 2006-07: Indicative Scenarios

\begin{tabular}{lccc}
\hline \hline \multicolumn{1}{c}{ Option } & Indicative Scenarios & \\
\hline Face value haircut & Discount & Discount & $0 \%$ \\
Grace period (years) & $20 \%$ & $20 \%$ & 12 \\
Final maturity (years) & 18 & 13 & 22 \\
& $2.5 \%$ until 2010 & 13 & $2 \%$ until 2010 \\
Coupon & $4.5 \%$ until 2012 & $4.5 \%$ until 2012 & $3.5 \%$ until 2013 \\
Repayment Style & $9 \%$ until 2025 & $9 \%$ until 2020 & $7 \%$ until 2029 \\
\hline \hline
\end{tabular}

Source: Belize authorities.

On December 18, 2006, after intensive dialogue with the creditors, the government launched the debt offer. Commercial debt eligible for exchange comprised (i) US\$348 million (29 percent of GDP) global bonds (including notes); (ii) bank notes for US\$53 million (4 percent of GDP); and (iii) two insured loans valued at US\$115 million (9 percent of GDP). The restructuring was executed through an exchange, with a single instrument dubbed as "super-bond". The "superbond" was a par-bond (i.e., no principal haircut) with a final maturity in 2029, amortization starting in 2019, and a step-up coupon structure (Table 2). With hindsight, this step-up coupon structure played a role in the authorities' decision to seek the second restructuring, as the government was anticipating increases in debt service by 0.6 and 1.2 percent of GDP in 2012 and 2013, respectively.

\footnotetext{
Belize Ministry of Finance (2006, p. 58).

Multilateral claims are often considered to be senior relative to other claims and are excluded from the exchange.

20 In particular, the authorities maintained close contact with over 40 creditors who held more than 80 percent of the face value of the total restructured debt.
} 
The details of financial terms at the exchange were the following (Table 2):

- No principal haircut. Approximately US\$546 million (45 percent of GDP) of new 2029 bonds were issued without face value reduction.

- Coupon rate reduction. Due to a step-up coupon structure, coupon rates of the new bond over maturity are lower by 2.1 percent than those of the old instruments on average.

- Maturity extension and change in repayment structure. Maturity was extended by 16 years on average. Contrary to payments due at maturity for a majority of old instruments $(85$ percent of total outstanding), the new bond is an amortizing bond commencing in August 2019.

- NPV and market haircuts. ${ }^{21}$ Using a discount rate of 9.2 percent, the NPV haircut was 24 percent, while the market haircut was 21 percent. NPV haircuts differ across creditors; NPV losses for holders of insured loans were 50 percent higher than those of global bonds and notes due to lower exchange ratio. ${ }^{22}$

Table 2

Belize Debt Restructuring, 2006-07: Deal Structure

\begin{tabular}{|c|c|c|c|c|}
\hline \multirow[b]{2}{*}{ Instruments } & \multicolumn{3}{|c|}{ Old Instruments } & \multirow{2}{*}{$\begin{array}{c}\text { New Instrument } \\
\text { Super-bond }\end{array}$} \\
\hline & Global bonds/notes & Bank loans & Insured loans & \\
\hline Face value (US\$ mil.) & 348 & 53 & 115 & 547 \\
\hline Face value haircut ${ }^{1)}$ & $0 \%$ & $0 \%$ & $0 \%$ & - \\
\hline Maturity & $2007-15$ & $2008-12$ & $2010-15$ & 2029 \\
\hline Grace period (years) $)^{2}$ & N/A & N/A & N/A & 12 \\
\hline $\begin{array}{l}\text { Remaining maturity } \\
\text { (years) }\end{array}$ & 6.2 & 4.4 & 5.8 & 22 \\
\hline Coupon & $\begin{array}{c}\text { Fixed } \\
8.95-9.95 \%\end{array}$ & $\begin{array}{c}\text { Fixed } \\
9.25-10 \%\end{array}$ & $\begin{array}{c}\text { Fixed } \\
10 \%\end{array}$ & $\begin{array}{l}4.25 \% \text { until } 2010,6 \% \text { until } \\
2012,8.5 \% \text { until maturity }\end{array}$ \\
\hline Repayment style & Amortizing/Bullet & Bullet & Bullet & Amortizing \\
\hline $\begin{array}{l}\text { Present value } \\
\left.\text { on } 2 / 2007^{3)} 4\right)\end{array}$ & $104 \%$ & $103 \%$ & $105 \%$ & $79 \%$ \\
\hline NPV haircut ${ }^{5) 6)}$ & $21 \%$ & $26 \%$ & $32 \%$ & - \\
\hline Market haircut ${ }^{6)}$ 7) & $18 \%$ & $23 \%$ & $29 \%$ & \\
\hline \multicolumn{5}{|c|}{$\begin{array}{l}\text { 1) Each instrument was exchanged based on "conversion factor" that varies from } 0.85 \text { to } 1.1 \text { with cash payments, without face value haircut. If the } \\
\text { face values of the existing instruments were multiplied by the respective conversion factor, they match with the face value of the super-bond. }\end{array}$} \\
\hline \multicolumn{5}{|c|}{ Grace period affects only capital requirements and not interest payments. } \\
\hline \multicolumn{5}{|c|}{$\begin{array}{l}\text { Discount rate of } 9.2 \text { percent was the exit yield at completion of the exchange (March 28, } 2013 \text { was the first transaction day when the yield was } \\
\text { recorded after completion of the exchange). }\end{array}$} \\
\hline \multicolumn{5}{|c|}{ Weighted average of all instruments following in the category based on outstanding as of $2 / 2007$} \\
\hline \multicolumn{5}{|c|}{$\begin{array}{l}\text { NVP haircut is defined as } 1 \text { - Present value of new debt/Present value of old debt as in Sturzenegger and Zettelmeyer (2006, 2008). Present } \\
\text { value of new debt and old debt is computed with the same discount rate. }\end{array}$} \\
\hline \multicolumn{5}{|c|}{ 6) Weighted average of all instruments following in the category based on outstanding as of 2/2007. } \\
\hline 7) Market haircut is defined a & 1 - Present value of new de & ace value of old & & \\
\hline
\end{tabular}

21 NVP haircut is defined as 1 - Present value of new debt/Present value of old debt as in Sturzenegger and Zettelmeyer (2006, 2008). Present value of new debt and old debt is computed with the same discount rate. On the contrary, market haircut is defined as 1 - Present value of new debt/Face value of old debt.

22 Exchange ratios define the principal amount of new bonds "Superbonds" to be exchanged for each of the eligible claims identified in Table 2. 
The debt exchange achieved 98-percent participation rate after the exercise of the collective action clause (CAC) (Annex 2). The CAC was triggered on the 9.75-percent note due 2015 (85-percent threshold of outstanding principal under New York law) on February 5, 2007 after the offer was closed. This raised the percentage of total eligible claims subject to exchange from 87 to 98 percent and facilitated the exchange. ${ }^{23}$ To this date, the remaining 2 percent of bondholders were not identified and did not take a significant legal litigation even without receiving debt service payments. Further, despite a large variety of restructured instruments with variations in NPV haircuts, the consolidation to one single bond did not seem to raise any significant intercreditor equity issues.

Creditors accepted the offer despite concerns about future debt distress. The offer memorandum for the 2006-07 debt exchange acknowledged the possibility of future debt exchanges in light of vulnerabilities and risks. ${ }^{24}$ However, creditors accepted the offer in the end, likely because (i) they thought the return profile was rewarding enough based on risk-adjusted assessment given the global environment; (ii) it was more economically sensible to accept the offer rather than take legal actions that may entail significant costs; and (iii) the original bonds were illiquid and thus the outright sales were not easy.

The IMF played its role as an independent party to provide debt sustainability assessment and cash flow analysis. It maintained close contact with both authorities and financial advisors, but not with creditors during the restructuring process. The 2006 Article IV consultation highlighting projected large financing gaps over the medium term provided essential inputs into an adjustment scenario that the authorities were preparing with their financial advisors (IMF, 2006a). At the request from the authorities of Belize, the IMF issued an assessment letter to the international financial community on December 20, 2006, right after the launch of the deal (IMF, 2006b). The letter noted that a high participation by private creditors would help support the authorities' "orderly macroeconomic adjustment, restore fiscal and external sustainability, and establish the conditions for strong economic growth."

The Belizean authorities also engaged with official multilateral and bilateral creditors to lend additional support to Belize. Although the official sector loans were not restructured, the authorities received substantial new concessional financing from the regional development banks, such as the Inter-American Development Bank (US\$25 million) and the Caribbean Development Bank (US\$25 million), as well as from official bilateral creditors, particularly Taiwan (US\$30 million) and Venezuela (US\$50 million).

\subsection{Outcomes}

The debt restructuring provided a significant liquidity relief, but solvency concerns remained unresolved. The average maturity of public external debt was extended from 5.7 years before the exchange to 22 years, which resulted in a substantial decline in debt service in the short run (Figure 2). ${ }^{25,26}$ Debt service relief amounted to US\$12 million (including the missed interest payments) in 2007 ( 1 percent of GDP) and about US\$38 million (2.6 percent of GDP) per year from 2008 to 2012. However, with no nominal haircut, the outstanding debt remained high at 86 percent of GDP in 2007, declining only gradually to 77 percent of GDP by 2012.

\footnotetext{
Buchheit and Karpinski (2007).

Belize Ministry of Finance (2006, p. 16).

Cash payments at the closing of the transaction were equal to the unpaid interest on tendered claims accrued up to the closing date.

Projected debt service schedule was similar to that of Argentina 2005 global debt restructuring: small debt service over the short term and substantial increase in debt payments over the medium and long terms due to amortization and step-up coupon structures.
} 
Figure 2

Belize Debt Restructuring, 2006-07: Debt Service of Old Instruments and Exchanged Bond ${ }^{1)}$ (In millions of U.S. dollars)

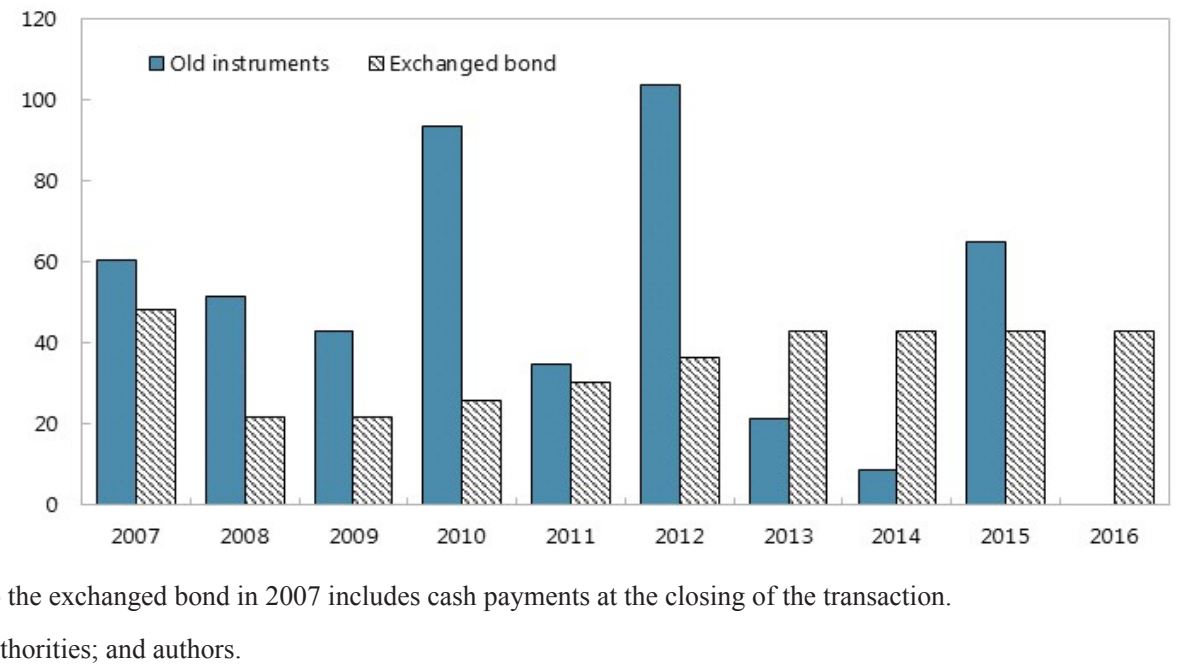

Belize enjoyed an immediate improvement in its credit ratings. Standard and Poor's raised Belize's credit rating on both its long- and short-term debt from CCC- to B immediately after the exchange. Moody's subsequently followed with an upgrade of Belize's sovereign debt to B3. By completion of exchange on February 15, 2007, the bond price recovered from 70 to 80 percent of the face value, close to the pre-announcement level (Figure 1).

After the completion of debt exchange, Belize did not access international capital markets. Although its emerging market bond index (EMBI) remained fairly low after the debt exchange (below 400 basis points for the next four months), Belize continued to rely on official project financing from both bilateral and multilateral creditors. In addition, the global financial crisis that occurred right after the debt exchange raised the risk sensitivity of creditors, preventing new external commercial debt issuances. ${ }^{27}$

No formal debt management and investor relations program was established after the restructuring. The debt restructuring in 2006-07 consolidated different debt instruments into one single bond, which would have facilitated regular interaction with foreign creditors. However, the government did not launch a formal debt management program and thus a regular and rigorous communication channel was not maintained after the completion of the first restructuring until start of negotiation on the second debt restructuring. Moreover, it should be noted that market participants were not convinced that the first restructuring would be sufficient to adequately address the debt sustainability concerns that led to this restructuring.

\section{2012-13 DEBT RESTRUCTURING}

The second debt restructuring followed a similar path to the previous one - preemptive and orderly process that achieved only a temporal liquidity relief. ${ }^{28}$ Notwithstanding the improvement in Belize's fiscal and external positions after the 2006-07 debt exchange, the country embarked on a new debt restructuring mainly driven by both a prospective increase in the debt service and medium-term debt sustainability concern - largely associated with potential compensation to the former shareholders of two nationalized companies. While negotiations did not proceed smoothly at the beginning, direct communication between high level officials and the head of the creditor

Excluding T-bills, Belize had not issued any domestic bonds at the local market.

28 Asonuma and Trebesch (2016) define Belize's 2012-13 restructuring as "weakly preemptive" as some payments were missed, but only temporarily and after the start of formal or informal negotiations with creditor representatives (no unilateral default). 
committee accelerated the process and eventually both parties reached an agreement. However, similar to the 2006-07 episode, the exchange provided only a substantial cash-flow relief over the near and medium terms, while debt sustainability concerns remain unaddressed.

\subsection{Background}

Following the 2006-07 restructuring, Belize's debt service burden and external position improved, liquidity pressures also softened relative to the financing needs (Annex 1). Debt servicing costs significantly tapered off as the central government interest payments dropped to about 16 percent of current revenues on average in 2007-11 compared to the average 25 percent in the preceding 5-year period. Gross financing needs declined to about 71/2 percent of GDP in 2007-12, compared with 25 percent of GDP in 2002-06.

The discovery of oil in mid-2005 provided temporary headroom for fiscal maneuver to service external debt and rein in the fiscal deficit. Oil-related revenues increased from 0.2 percent of GDP in 2006 to 2.9 percent in 2011, boosted by peaks in production at the main commercial well-elevated world crude prices, and an additional tax. Rising oil exports also bolstered Belize's external position, as the current account deficit narrowed to 4.7 percent of GDP on average in 2007-11 compared to the average 13.3 percent in 2002-06. Combined with steadily-increasing substantial FDI inflows, gross international reserves went from 2.1 months of imports in 2008 to 3.2 months on average in 2009-11.

Meanwhile, Belize's growth performance was lackluster, due mainly to structural vulnerabilities and exogenous weather shocks. Real growth declined in the period between the two debt exchanges - averaging 1.9 percent in 2007-11 compared with 5.4 percent on average in 2002-06 - when growth was spurred by expansionary fiscal policies. While oil production boosted output growth, traditional sectors of the economy decelerated, reflecting structural weaknesses and the impact of severe weather-related shocks, which contributed to output losses, mostly in agriculture, and damaged infrastructure. In 2008, two tropical storms caused direct economic losses estimated at about US\$75 million (5.4 percent of GDP), with a negative balance of payments impact of US\$46 million.

The authorities continued to face spending pressures, including those associated with the "super-bond" step-up coupon. According to the authorities, the economic slowdown, increased poverty, a surge in crime, and the associated need for increased citizen security constrained their efforts to engage in a more aggressive fiscal consolidation. Moreover, while Belize faced lower interest payments over the period 2008-12 than anticipated after the 2006-07 restructuring (2.8 percent of GDP vs. 4.6 percent of GDP, respectively), the authorities started to be concerned about the step-up coupon structure, as it was due to rise to 8.5 percent in 2012 (from 4.25 percent in 2007 and 6 percent in 2010), implying about 0.6 percent of GDP in additional interest payments in 2012 and 1.2 percent in 2013.

In addition, Belize faces significant additional claims associated with the nationalization of two public utility companies and the enforcement of several arbitration awards. The government nationalized the Belize Telemedia Limited (BTL) in 2009 and Belize Electricity Limited (BEL) in $2011 .{ }^{29}$ While the government is required to pay the compensations to former owners of these companies, no agreement has been reached as of end-December 2016 between the government and the former owners on the amount of compensation. The valuation of the companies ranges from 6 percent of GDP (government valuation) to 30 percent of GDP (former owners' valuation), and depending on the court's ruling regarding the compensation amount, would amplify the

\footnotetext{
29 In 2009, the government started to negotiate with BTL on how to address a series of allegedly illegal agreements between the BTL and the previous administration. Following failure of such efforts, it enacted legislation to acquire the shareholding in BTL. In 2011, the government nationalized the BEL to ensure continuous electricity supply to the public, following the company's proclamation that it would execute rolling blackouts in the country in response to its financial difficulties.
} 
debt-to-GDP ratio, which at end-2012 stood at 79 percent. In addition to these claims, several arbitral awards related to land acquisition, overpayment of taxes, and non-observance of tax agreement have been delivered against the government and are pending enforcement. ${ }^{30}$ While IMF's Debt Sustainability Analysis in 2011 did not explicitly raise debt sustainability concerns over the medium term, it alerted that the debt ratio would be elevated by 17 percent of GDP if fiscal contingent liabilities materialize. ${ }^{31}$

Prime Minister Barrow made the restructuring of the "super-bond" an electoral issue in the March 2012 general election. Similar to the 2006-07 debt exchange, the authorities targeted only external commercial debt, while the creditors did not raise inter-creditor equity issues. Some market participants viewed that the debt restructuring was driven by lack of the "willingness" to service external liabilities, not the lack of "ability", given no expected immediate liquidity shortage. ${ }^{32}$ The bond price plunged to 40 percent of the face value, while no immediate outright sales occurred likely owing to the lack of liquidity in the secondary market.

\subsection{Process}

After securing his re-election in March 2012, Mr. Barrow announced the appointment of a debt review team to conduct a comprehensive review of external public debt and contingent liabilities. ${ }^{33}$ At the same time, the authorities also engaged the financial advisors for restructuring. ${ }^{34}$ The Belizean authorities explicitly identified the additional liabilities associated with the nationalization as one of the driving forces of debt restructuring, along with the onerous step-up coupon. However, as negotiations with previous owners of nationalized companies stalled, the government focused on debt burden stemming from high coupon rate, effectively de-linking the debt restructuring and the additional liabilities issues. On June 20, 2012, the authorities published an economic and financial update, showing that despite active engagement with multilateral partners, Belize was facing sizeable financing gaps from 2013 onwards. ${ }^{35}$

The reaction by investor community was swift and well-organized, while the authorities' initial approach was not viewed as collaborative. Prior to the authorities' economic and financial update, a group of bondholders announced the creation of a creditor committee representing US $\$ 200$ million of the "super-bond". 36,37 This swift reaction by the bondholders stemmed from growing 'readiness' for sovereign debt restructuring and debt negotiation, owing to their accumulated experiences from a series of smooth debt negotiations in the Caribbean region, including the first Belize's debt restructuring. However, the authorities and the creditors were pursuing different strategies in negotiating the terms of the debt exchange. While the authorities aimed to reduce debt service via substantial face value reduction, the creditors targeted a longterm coupon reduction with no steep step-up. Due to this difference in restructuring strategies, the creditor committee rejected the authorities' first indicative scenarios published in August

\footnotetext{
30 Central Bank of Belize (2012) extensively discusses the additional liabilities.

IMF (2011).

32 In February 2012, S\&P downgraded twice Belize's long-term foreign-currency rating to CCC- (three notches in total) noting, first, the lower political willingness to service the country's external commercial debt and, second, the increasing likelihood that Belize would seek to restructure its sovereign external debt.

33 Belize Press Office, Government of Belize Initiates External Public Sector Debt Review, March 19, 2012, https://www.centralbank.org.bz/ news/details?newsid=23.

34 BroadSpan Capital LLC and Blitzer Consulting acted as the Committee's financial advisers, while Arnold \& Porter LLP was retained as the Committee's legal advisor. White Oak Advisory LPP was the financial advisor for the Government of Belize, and Cleary Gottlieb Steen \& Hamilton LLP, Houlihan Lokey Howard \& Zukin was acting as the government's legal advisor (Belize Ministry of Finance, 2013b and Coordinating Committee of Belize, 2013).

35 https://www.centralbank.org.bz/news/details?newsid=29.

36 Belize Coordinating Committee Announces Formation, Press Release, June 13, 2012.

37 The Coordinating Committee and an ad-hoc group of bondholders which consists of 20 additional institutional members represented over US\$338 million, i.e. about 62 percent of the US\$547 million of bonds outstanding.
} 
2012 that implied substantive face value and NPV haircuts with coupon reduction and maturity extension (Table 3).

A partial coupon payment opened ground for extending debt exchange negotiations. On August 21, 2012, the Government of Belize missed a US\$23 million coupon payment on the "super-bond" resulting in S\&P's downgrading the country to a default rating. Then, on September 20,2012 - one day after the expiration of the 30-day grace period of missed payment - the authorities made a partial coupon payment of US\$11.7 million and the creditor committee agreed to give Belize 60 more days to conclude debt restructuring negotiations.

Negotiations between the government and the creditor committee started in earnest in early October 2012. ${ }^{38}$ The focus of the negotiations included growth projection, potential amount of the additional liabilities associated with the nationalization of the two utility companies, and availability of external official financing. ${ }^{39}$ These three elements were essential ingredients to determine the financing gaps and the associated creditor loss to be agreed. Subsequently, on November 21, 2012, the creditor committee made a counter proposal, which included par bonds with more modest creditor loss in NPV terms than the authorities' original indicative scenarios. This proposal was followed by the authorities' revised indicative scenarios that entailed lighter face value haircut and higher coupon rate than the original proposal. These revised scenarios were, however, also rejected by the creditor committee. Details of the government's indicative scenarios are presented in Table 3 below.

Table 3

Belize Debt Restructuring, 2012-13: Initial and Revised Indicative Scenarios

\begin{tabular}{|c|c|c|c|c|c|}
\hline \multirow[b]{2}{*}{ Option } & \multicolumn{3}{|c|}{ Initial Indicative Scenarios (Aug 9) } & \multicolumn{2}{|c|}{ Revised Indicative Scenarios (Nov 29) } \\
\hline & Par & Discount & Discount & Par & Discount \\
\hline Face value haircut & $0 \%$ & $45 \%$ & $45 \%$ & $0 \%$ & $33 \%$ \\
\hline Grace period (years) & 15 & 0 & 5 & 10 & 5 \\
\hline Final maturity (years) & 50 & 30 & 30 & 40 & 30 \\
\hline Coupon & $2 \%$ & $\begin{array}{l}1 \% \text { until } 2019 \\
2 \% \text { until } 2026 \\
4 \% \text { until } 2042\end{array}$ & $3.50 \%$ & $\begin{array}{c}2.75 \% \text { until } 2018 \\
4.5 \% \text { until } 2053\end{array}$ & $\begin{array}{l}4.5 \% \text { until } 2018 \\
6.75 \% \text { until } 2043\end{array}$ \\
\hline Repayment Style & Amortizing & Amortizing & Mortgage & Mortgage & Mortgage \\
\hline
\end{tabular}

Source: Belize authorities.

The high-level intensive discussion after the rejection of the revised indicative scenarios helped both parties to reach an agreement on the terms of the exchange offer. After refusing the revised indicative scenarios, the committee expressed its view that both sides would be missing the window for a timely resolution of the impasse. Right after the rejection, the direct communication between the authorities and the creditor committee, including direct dialogue between Mr. Barrow and the co-chair of the committee, started, leading to a framework agreement between both parties. However, the underlying considerations of the participants in assessing the offer cannot be readily ascertained. ${ }^{40}$ The anticipated execution of the bond exchange pushed up the bond price to the pre-exchange announcement level. The exchange offer was launched on

\footnotetext{
38 https://www.centralbank.org.bz/news/details?newsid=51.

39 Belize Ministry of Finance (2012).

40 http://edition.channel5belize.com/archives/79952.
} 
February 15, 2013 and the CAC (75-percent threshold under New York law) was executed to raise the participation rate from 86 percent to a full participation. The debt exchange operation was closed on March 20, 2013.

The restructuring financial terms were the following (Table 4):

- Principal haircut. Approximately US\$530 million of new 2038 bonds were issued. The original "super-bond" was subject to a 10 percent face value haircut, but overdue interest was added to the face value of the new bond (approximately 7 percent of the original principal). ${ }^{41}$ As a result, the "net" face value haircut was about 3 percent.

- Coupon rate reduction. The new bond will pay a step-up coupon of 5 percent without grace period through 2017 (for 4.5 years) and 6.767 percent thereafter, compared with the original 8.5 percent through maturity.

- Maturity extension. The final maturity will be February 2038 (instead of 2029 under the original "super-bond" terms), with the first amortization falling due in August 2019, while the grace period remained unchanged.

- NPV and market haircuts. Using a discount rate of 9.2 percent, the NPV haircut was 29 percent, while the market haircut was 33 percent.

Table 4

Belize Debt Restructuring, 2012-13: Deal Structure

\begin{tabular}{|c|c|c|}
\hline & Old Instrument & New Instrument \\
\hline Instruments & $\begin{array}{l}2029 \text { US bond } \\
\text { ("super-bond") }\end{array}$ & 2038 US bond \\
\hline Face value (US\$ mil.) & 547 & 530 \\
\hline Face value haircut & $10 \%(3 \%)^{1)}$ & - \\
\hline Maturity & 2029 & 2038 \\
\hline Remaining maturity (years) & 16 & 25 \\
\hline Coupon & $\begin{array}{l}4.25 \% \text { until } 2010,6 \% \text { until } 2012 \text {, } \\
8.5 \% \text { until maturity }\end{array}$ & $\begin{array}{l}5 \% \text { until } 2017, \\
6.767 \% \text { until maturity }\end{array}$ \\
\hline Repayment profile & $2019-29$ & 2019-38 \\
\hline Present value on $3 / 2013^{2)}$ & $94 \%$ & $67 \%$ \\
\hline NPV haircut ${ }^{3}$ ) & $29 \%$ & - \\
\hline Market haircut ${ }^{4)}$ & $33 \%$ & - \\
\hline
\end{tabular}

1) Face value haircut was 10 percent. Adding the missed coupon payments to the face value, the net face value haircut is 3 percent.

2) Discount rate at 9.2 percent which was exit yield at completion of exchange (on $3 / 28 / 2013$ - the first transaction day when yields were recorded after completion of exchange).

3) NVP is defined as 1 - Present value of new debt/Present value of old debt as in Sturzenegger and Zettelmeyer (2008). Present value of new debt and old debt is computed with the same discount rate.

4) Market haircut is defined as 1 - Present value of new debt/Face value of old debt.

Sources: Belize authorities; and authors.

The debt exchange offer included several new legal terms, most notably a committee engagement provision (Annex 3). In contrast to recent sovereign debt restructurings, the government of Belize and the creditors' committee agreed to a more extensive bondholders'

41 The missed coupon payments (August 2012 and February 2013) amounted to about US\$35 million. 
committee engagement provision to augment, among others, contract enforceability. ${ }^{42}$ Given the circumstance where no IMF-supported program is in place, both parties agreed to maintain a close engagement if the government experiences difficulties to service its debt obligations.

Other new terms included a contingency account for trustee indemnification, principal reinstatement in the event of a future default, and a most favored creditor provision. In addition, Belize clarified the pari passu clause to mean equal ranking in the legislation authorizing the exchange together with the exchange offer. ${ }^{43}$ Also, the government has committed to improve data transparency, through its "best effort" to begin to subscribe to the Special Data Dissemination Standard (SDDS).

As in the 2006-07 restructuring, the IMF did not participate directly in the restructuring process through an adjustment program. However, while maintaining neutrality during the debt exchange process, IMF staff was in close contact with both the authorities and the financial advisors. An IMF mission visited Belize from November 1-15, 2012 to conduct the yearly review of the country's economy, in the context of the IMF's Article IV consultations. However, in light of ongoing negotiations with bondholders on the restructuring of the "super-bond", further discussions with the authorities were required to complete the consultations. Discussions resumed in April 2013 and were completed in June 2013. In parallel with the Article IV consultations, a technical assistance mission assessed the current framework for debt management and helped the authorities build relevant institutional capacity.

While no credit enhancements were formally offered to bondholders, the authorities initially considered an operation with the IDB to fund a partial guarantee. ${ }^{44}$ Similar guarantees were used for recent debt restructuring cases: guarantees of US\$10 million were provided to Seychelles in 2010 by the African Development Bank and of US\$12 million to St. Kitts and Nevis in 2012 by the Caribbean Development Bank. In both cases, guarantees not only complemented part of interest payments of new discount bonds, but also played a catalytic role in assuring confidence in the country's macroeconomic adjustment program. In Belize's case, the authorities approached the IDB at the early stage of the debt exchange negotiations and discussed the possibility of provision of a partial guarantee by the IDB. However, as negotiations between bondholders and the government intensified toward the end of 2012, the IDB and the Belizean authorities began discussion on alternative ways to support the country. ${ }^{45}$

\subsection{Outcomes}

The deal provided substantial cash-flow relief over the near term (Figure 3). The reduced coupon, along with the modest face value haircut, would result in debt service relief of US\$47 million (including the missed interest payments) in 2013 (2.9 percent of GDP) and about US\$20 million (1.1 percent of GDP) per year from 2014 to 2017. Over the remaining 16-year life of the original "super-bond", total cash-flow relief will be US\$384 million. On the contrary, Belize will face continuous liquidity needs over the long term until 2038, indicating the need for frontloaded macroeconomic adjustment policies.

\footnotetext{
42 The most notable examples of creditor engagements were those of Hungary in its late 2004 and early 2005 offerings. The 2004 English law offering document disclosed the usual industry-model engagement clause; however, less than a year later, Hungary's New York law issue included an engagement clause without an undertaking to pay the committee's expenses.

43 Rather than modifying the terms of instruments, the authorities used a new technique to clarify the meaning of the clause in disclosure documents.

44 Central Bank of Belize, 2012 Annual Report and Statement of Accounts, pp. 44-45.

45 http://www.reporter.bz/front-page/no-idb-guarantee-but-negotiations-will-go-on/.
} 


\section{Figure 3}

Belize Debt Restructuring, 2012-13: Debt Service of Old Instruments and Exchanged Bond ${ }^{1)}$ (In millions of U.S. dollars)

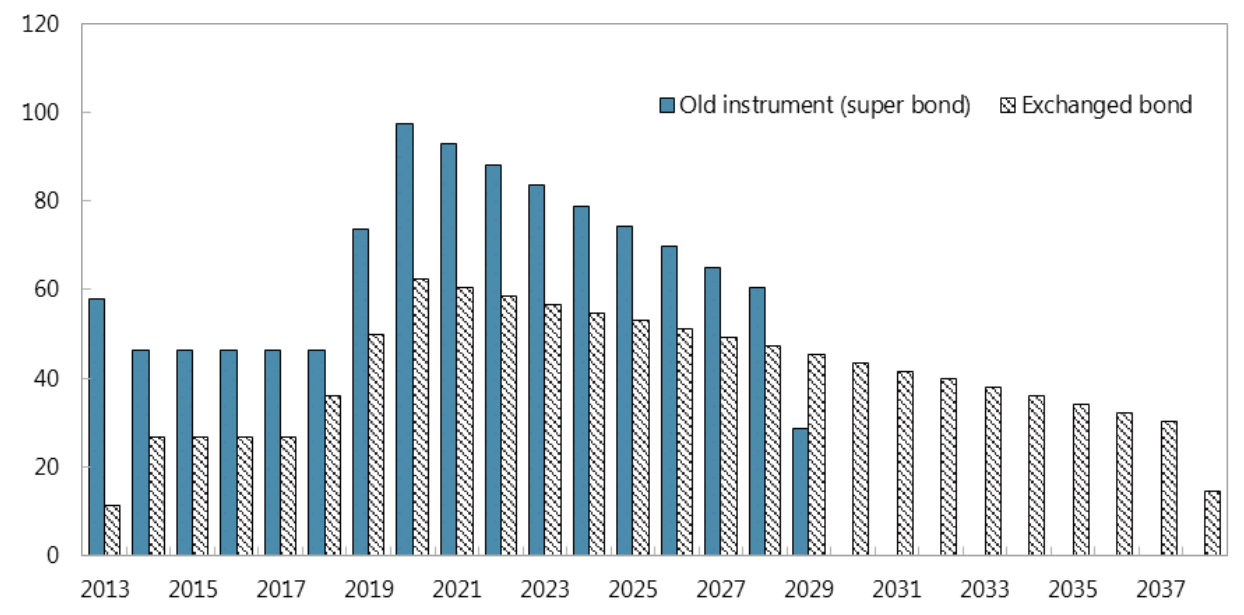

Sources: Belize authorities; and authors.

The credit ratings were upgraded immediately after the debt restructuring, with a significant drop in EMBI spread. S\&P upgraded Belize to non-default rating (B-) on March 20 given expected completion of the debt exchange, followed by an upgrade by Moody's from Ca to Caa2 on April 15, reflecting an improvement in the government's liquidity position. ${ }^{46}$ Further, the bond price recovered from 60 to 65 percent of the face value (Figure 4).

Figure 4

Belize: External Bond Price and Credit Rating Development, 2010-13

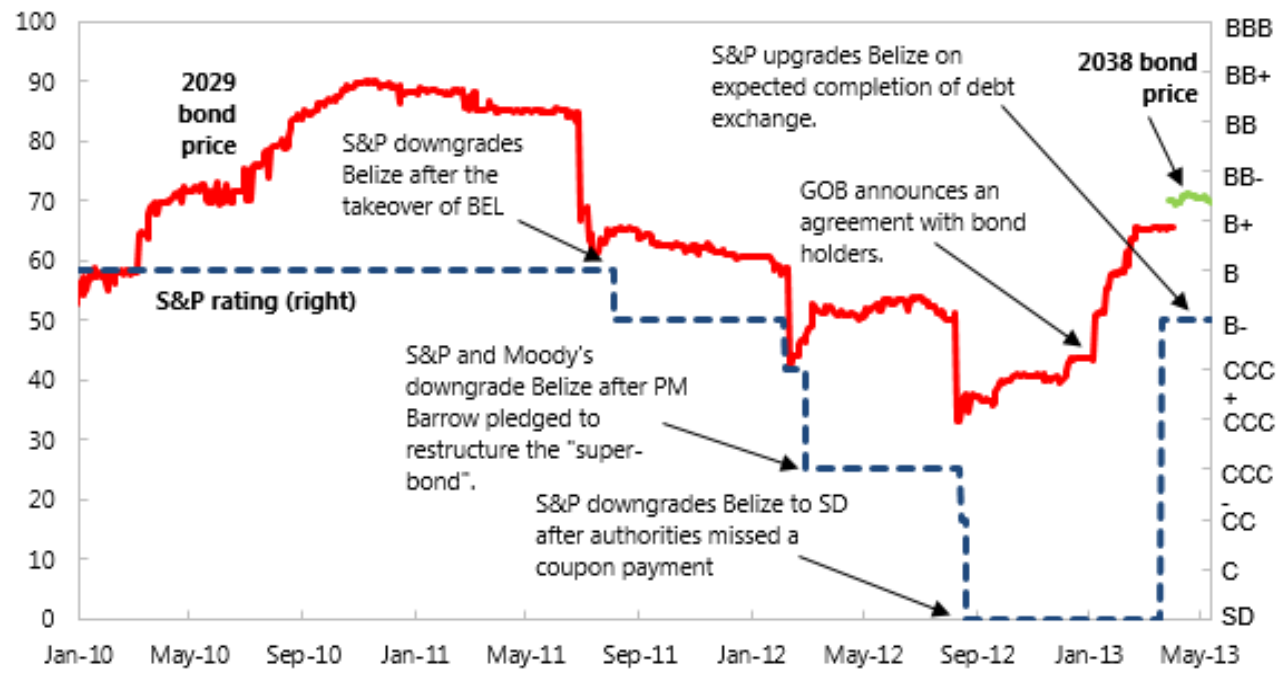

Sources: Bloomberg; Standard and Poor's; and authors.

Despite the cash-flow relief, concerns over public debt sustainability and external stability remain mostly due to liquidity needs over the long term, necessitating strong fiscal policy efforts. Our calculations suggest that the debt exchange would reduce the debt-to-GDP ratio by around 8 percent in 2018. Although the debt path would be ceteris paribus more favorable after the restructuring, there still remains uncertainty about the size, modality, and timing of the possible compensation payments to the former owners of the two nationalized companies.

46 Standard and Poor's (2013) explains that credit ratings on Belize are constrained by its weak political institutions, weak medium-term growth prospects which are weaker than those of peers rated in the B category, limited financing options reflecting shallow domestic capital market, and potential risk of contingent liabilities to the government's ability to service its newly issued debt. 
The compensation payments could increase the debt level by 17 percent of GDP at end-2015 and push up the financing needs to above $6 \frac{1}{2}$ percent of GDP in 2016, and to more than 7 percent of GDP after 2018. ${ }^{47}$ Unless the authorities adhere to an active fiscal adjustment policy that will help contain growing financing needs and achieve a faster downward debt trajectory, the debt level will remain elevated. ${ }^{48}$

The government of Belize is committed to revamp the public debt management framework, and the reform is underway. The current administration announced its intention to "modernize" the debt management framework after the debt restructuring. ${ }^{49}$ Robust debt management scheme with solid medium-term debt management strategy will help the authorities monitor various risks that are inherent in the public debt portfolio. However, even the second restructuring was not able to persuade market participants and analysts that debt sustainability had been restored and no further restructurings would be needed.

\section{CONCLUSION}

In this paper, we analyzed the causes, processes, and outcomes of Belize's two consecutive sovereign debt restructurings, as unique cases of not involving the IMF-supported (adjustments) programs. Also it was indicated that the underlying motivation for the sovereign debt restructurings of 2006-07 and 2012-13 was different. The former was driven by external liquidity concerns while the latter was motivated by a substantial increase in the coupon rates and future fiscal solvency concerns. Some market participants had a different take, particularly with respect to the second restructuring. They recognized that the 2006-07 debt exchange was largely motivated by liquidity concern, but they viewed the 2012-13 debt exchange as driven by a lack of "willingness" to pay. A difference in understanding of the underlying motivation of the second restructuring negatively affected the smoothness of the negotiation process, at least at its initial stage.

Both debt restructurings were undertaken in a preemptive and broadly transparent manner despite explicit discrimination between residents and non-residents. A successful collaboration between the government and creditors in the first restructuring paved the way for the second restructuring through shared experience of renegotiation. Further, the representation of the creditor committee was also high in particular in the second debt restructuring - 62 percent of the US\$547 million of bonds outstanding - which helped contain potential holdouts.

Belize introduced a number of new legal provisions to facilitate engagement with creditors. Examining the implications of the new legal provisions for future sovereign restructurings goes beyond this paper. In the 2006-07 restructuring, the exercise of CAC smoothed negotiations to yield high participation of creditors. In the 2012-13 restructuring, a more extensive bondholders' committee engagement provision was included to augment contract enforceability in the future. Other new terms included a contingency account for trustee indemnification, principal reinstatement in the event of a future default, and a most favored creditor provision.

However, debt sustainability has not been effectively restored following the two restructurings, thus calling for more robust macroeconomic policy adjustments (Annex 1). Smooth debt renegotiation process did not necessarily guarantee successful outcomes. Even after the repeated debt exchanges, Belize still remains vulnerable both to external shocks (including weather) and domestic shocks, with debt sustainability overshadowed by the looming additional fiscal contingent liabilities. Despite plans to revamp the public debt management framework, further

\footnotetext{
47 Due to high uncertainty surrounding the nationalization compensation, the calculations are based on the assumptions, and are for illustration purpose. For further details, see IMF (2013b).

48 IMF (2013b) suggests that raising gradually the primary surplus to 3 percent of GDP over the medium term - 1 percent of GDP above the average over the last 10 years - would help reduce the debt-to-GDP ratio to less than 60 percent of GDP a decade from now and to below the longterm value of 50 percent of GDP by mid-2020s.

49 Belize, Ministry of Finance, “Achieving debt sustainability, Stimulating economic expansion”, Budget Presentation for Fiscal Year $2013 / 2014$.
} 
fiscal consolidation to achieve debt sustainability and reduce future financing needs have not been attained, leading to the authorities' announcement on November 9, 2016 to start new restructuring discussions with bond holders. In light of the recent developments, further research is warranted focusing on appropriate measures on fiscal consolidations that could address future debt sustainability concerns.

\section{Acknowledgements}

This is an extended version of the IMF Working Paper "Sovereign Debt Restructurings in Belize: Achievements and Challenges Ahead" (WP 14/132). The views expressed in this paper are those of the authors and should not be attributed to the International Monetary Fund, its Executive Board or its Management, as well as to the Japanese Ministry of Finance. We would like to express our thanks for helpful comments and suggestions to the editor, two anonymous referees, Charles Blitzer, Spencer Jones, and Rafael Molina. The usual disclaimer applies.

\section{References}

Asonuma, T. (2016) Serial Sovereign Defaults and Debt Restructurings. IMF Working Paper WP/16/66.

Asonuma, T., Papaioannou, M.G., (2016), Domestic Sovereign Debt Restructurings: Process, Outcomes and Challenges. manuscript, IMF.

Asonuma, T., Li, M.X., Papaioannou, M.G., Thomas, S., and Togo, E., (2017a), Sovereign Debt Restructurings in Grenada: Causes, Processes, Outcomes and Lessons Learned, forthcoming as IMF Working Paper.

Asonuma, T., Niepelt, D., and Ranciere R., (2017b), Sovereign Bond Prices, Haircuts and Maturity, IMF Working Paper WP/17/119.

Asonuma, T., and Trebesch, C. (2016) Sovereign Debt Restructurings: Preemptive or Post-Default. Journal of the European Economic Association, Vol. 14 (1), pp. 175-214.

Belize, Ministry of Finance. (2006) Offering Memorandum, December 18, 2006.

—. (2012) Memorandum, November 29, 2012.

- (2013a) Offering Memorandum, February 15, 2013.

. (2013b) Press Release, March 20, 2013.

. (2013c). Achieving Debt Sustainability, Stimulating Economic Expansion. Budget Presentation for Fiscal Year 2013/2014.

Buchheit, L.C. (2009) Use of Creditor Committees in Sovereign Debt Workouts. Business Law International, Vol. 10, pp. 205-217.

Buchheit, L.C. and Karpinski, E. (2007) Belize's Innovations. Journal of International Banking and Financial Law. May 2007: pp. 278-280.

Buchheit, L.C. and Pam, J.S. (2004) The Pari Passu Clause in Sovereign Debt Instruments. Emory Law Journal, Vol. 53, pp. 870-922.

Catao, L.A.V., Fostel, A., and Kapur, S. (2009) Persistent Gaps and Default Traps. Journal of Development Economics, Vol. 89 (2). pp. 271-284.

Central Bank of Belize. (2012) Economic and Financial Updates, June. . 2013, 2012 Annual Report and Statement of Accounts.

Coordinating Committee of Belize. (2013) Press Release. February 19, 2013.

Das, U., Papaioannou, M., and Trebesch, C. (2012). Sovereign Debt Restructurings 1950-2010: Literature Survey, Data and Stylized Facts," IMF Working Paper, WP/12/203.

Diaz-Cassou, J., Erce-Dominguez, A., and Vazquez-Zamora, J.J. (2008) Recent Episodes of Sovereign Debt Restructurings. A Case-Study Approach. Bank of Spain Working Paper, No. 0804.

Duggar, E. (2013) The Role of Holdout Creditors and CACs in Sovereign Debt Restructurings. Moody's Sovereign Default Series Compendium, October 7, 2013.

Eichengreen, B., Hausmann, R., and Panizza, U. (2003) The Mystery of Original Sin. eds. by B. Eichengreen and R. Hausmann in Other People's Money - Debt Denomination and Financial Instability in Emerging Market Economies, University of Chicago Press. 
Erce-Dominguez, A. (2013) Sovereign Debt Restructurings and the IMF: Implications for Future Official Interventions. Federal Reserve Bank of Dallas Globalization and Monetary Policy Institute Working Paper No. 143.

. and Diaz-Cassou, J. (2010) Creditor Discrimination during Sovereign Debt Restructurings. Bank of Spain Working Paper, No. 1027.

Finger, H., and Macagni, M. (2007) Sovereign Debt Restructurings and Debt Sustainability - An Analysis of Recent Cross-Country Experience. IMF Occasional Paper No.255.

International Monetary Fund. (2002a) Belize: Staff Report for the 2002 Article IV Consultation. IMF Country Report No. $02 / 255$.

. (2002b) The Design and Effectiveness of Collective Action Clauses. International Monetary Fund, Washington, DC.

- (2006a) Belize: Staff Report for the 2006 Article IV Consultation. IMF Country Report No. 06/360.

. (2006b) Belize-Assessment Letter for the International Financial Community.

- (2011) Belize: Staff Report for the 2011 Article IV Consultation. IMF Country Report No. 11/340.

- (2013a) Sovereign Debt Restructuring: Recent Developments and Implications for the Fund's Legal and Policy Framework. IMF Board Paper, April.

. (2013b) Belize: Staff Report for the 2013 Article IV Consultation. IMF Country Report No. 13/227.

Jahan, S. (2013) Experiences with Sovereign Debt Restructuring: Case Studies from the OECS/ECCU and Beyond. in Schipke, A., Cebotari, A., and N. Thacker, eds. "The Eastern Caribbean Economic and Currency Union: Macroeconomic and Financial System," International Monetary Fund (Washington, DC).

Panizza, U., Sturzenegger, F., and Zettelmeyer, J. (2009) The Economics and Law of Sovereign Debt and Default. Journal of Economic Literature, Vol. 47, pp. 651-698.

Reinhart, C., Rogoff, K., and Savastano, M. (2003) Debt Intolerance. Brookings Papers on Economic Activity, Vol. 1, Spring 2003, pp. 1-74.

Reinhart, C.M., and Rogoff, K.S. (2005) Serial Default and the "Paradox" of Rich-to-Poor Capital Flows. The American Economic Review, Vol. 94 (2), pp. 53-58.

- (2009) This Time is Different - Eight Centuries of Folly, Princeton University Press.

Robinson, M. (2010) Debt Restructuring Initiatives Paper. paper prepared for the Commonwealth Secretariat.

Standard \& Poor's. (2005) Research Update: Belize Long-term Ratings Lowered, Outlook Negative. Ratings Direct. April 2005.

- (2013). Ratings on Belize Raised to 'B-/B' on Expected Completion of Debt Exchange; Outlook Stable; Bonds Due in 2038 Rated 'B-'", RatingsDirect. March 2013.

Sturzenegger, F., and Zettelmeyer, J. (2006) Debt Defaults and Lessons from a Decade of Crises, Cambridge, MA: MIT Press.

Sturzenegger, F., and Zettelmeyer, J. (2008) Haircuts: Estimating Investor Losses in Sovereign Debt Restructurings, 1998-2005. Journal of International Money and Finance, Vol. 27 (5), pp. 780-805.

Tomz, M., and Wright, M.L.J. (2013). Empirical Research on Sovereign Debt and Default. Annual Review of Economics, Vol. 5, pp. 247-272. 


\section{ANNEX 1.}

Figure

Belize: Selected Economic Indicators, 2000-151)
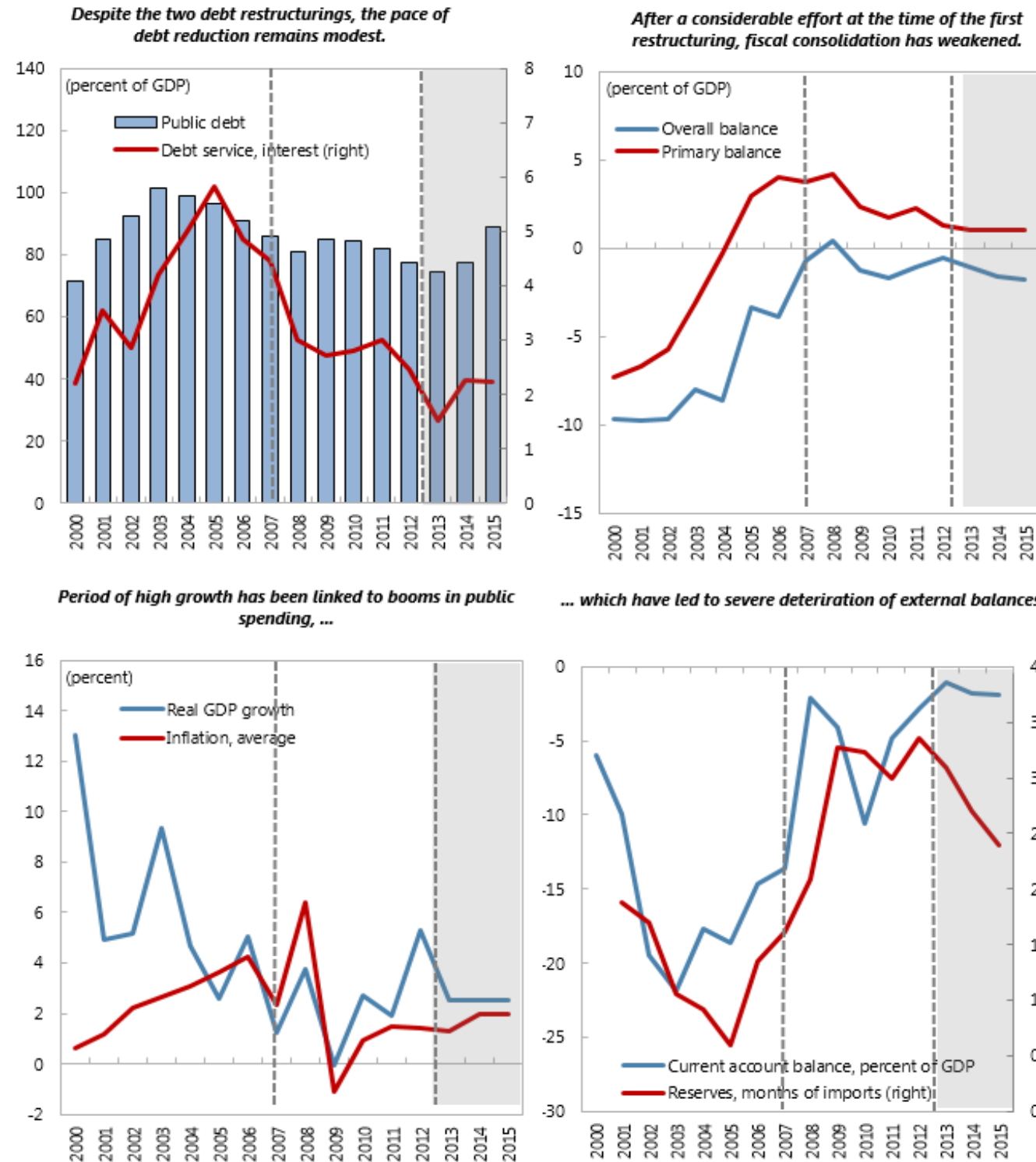

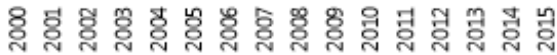

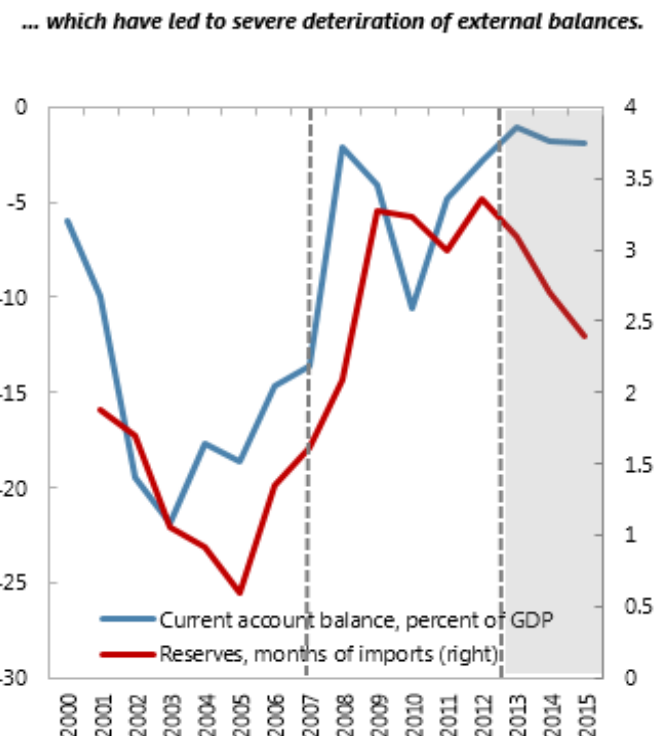

1) Dotted vertical lines represent debt restructurings in 2007 and 2013. Shaded area represents projection years.

Sources: Belizean authorities; and IMF staff estimates and projections. 


\section{ANNEX 2. \\ Collective Action Clause in Belize 2006-07 Restructuring}

Belize employed collective action clause (CAC). This Annex illustrates key characteristics of these instruments.

\section{CACs}

CACs can be classified into two broad categories (see IMF, 2002b):

- "Majority restructuring" provisions, which allow a qualified majority of bondholders of an issuance to change the bonds' financial terms (principal, interest, and maturity) and to bind in all other holders of that issuance, either before or after default. For most recently issued bonds with CACs, a supermajority is reached when bondholders holding a certain percentage of total outstanding debt agree (e.g., 75 percent).

- "Majority enforcement" provisions, which can limit the ability of minority bond holders to enforce their rights following a default. In practice, this means that a qualified majority can prevent individual bondholders from (i) declaring the full amount of bond due and payable ("acceleration"), and (ii) commencing litigation against the sovereign.

In the Belize's case, the authorities issued a 9.75 percent bond with face value of US\$100 million due 2015 under New York law in the $1^{\text {st }}$ half of 2003 that included "majority restructuring" provision with a written consent of holders owning at least 85 percent of the notes. Holders of 87.3 percent of the bond accepted Belize's exchange offer, thereby consenting to the amendments, which included matching the terms of the old bonds with those of the new bonds.

Two key features of CAC used in Belize 2006-07 restructuring (Buchheit and Karpinski, 2007) include:

- While in most countries the required threshold to amend the terms of the bonds containing majority restructuring clauses has been 75 percent of the aggregate principal amount of the outstanding bonds, Belize is the only country that has required 85 percent.

- Belize was the first sovereign in more than 70 years to use a CAC to amend the payment terms of bonds in sovereign debt restructuring. 


\section{ANNEX 3. \\ Legal Terms in 2012-13 Exchange Offer ${ }^{1}$}

The 2012-13 exchange offer includes various legal terms, in addition to the CACs that were used in the 2006-07 debt exchange. ${ }^{2}$ Among others, the committee engagement provision was newly introduced and unique to Belize case.

- Committee engagement provision. It represents commitment from the sovereign debtor "to recognize and to engage with a Creditor Committee" (i) in the event of a future default, (ii) any event or circumstance which would, with the giving of notice, lapse of time, the issuing of a certificate and/or fulfillment of any other requirement, constitute an event of default, or (iii) any public announcement by the debtor to the effect that the debtor is seeking or intends to seek a restructuring of the securities (whether by amendments, exchange offer or otherwise).

- Minimum participation threshold. It ensures that a high number of bondholders agree on exchange offer. Sovereigns reserve the right, in its sole discretion, to cancel the proposed offer in the event that the level of participation in the proposed offer would not exceed the threshold. These clauses have been used to reassure tending bondholders that they would not be left out holding a smaller and illiquid claim in the event that most bondholders chose not to accept the offer. In Belize's case, this minimum threshold was set at 75 percent of the aggregate principal amount of the eligible claims.

- The Most-Favored-Creditor provision. It lets creditors know that the sovereign debtor will not settle, by negotiation, any other outstanding claim on better terms that it has offered holders of the old bonds.

- Principal reinstatement provision. It states an automatic upward adjustment in principal in the event of a future default. Specifically, upon a default, the authorities shall issue to each holder of the exchanged bond within 5 business days after the principal reinstatement date an amount of additional exchange bond equal to 11.11 percent of the outstanding principal amount of exchange bond as of the date of original issuance of the new bonds.

- Pre-funding of a Trustee Contingency Account. It specifies that a sovereign debtor pays the funding of Contingency Account which is available for reimbursement of expenses of the Trustee of New Bonds.

- The Pari Passu clause. It ensures that the borrower does not have, nor will it subsequently create, a class of creditors whose claims against the borrower will rank legally senior to the indebtedness represented by the loan agreement (Buchheit and Pam, 2004).

Belize Ministry of Finance (2013a).

2 Although CACs can play an important role in facilitating debt restructurings, their presence is no guarantee for a quick exchange with high participation. Other legal vehicles and exchange characteristics, in particular exit consents, aggregation clauses and minimum participation thresholds can play a role as well (Das et al., 2012). 